САИДОВ Санжар Шавкатович - политолог Узбекского государственного университета мировых языков (100138, Республика Узбекистан, г. Ташкент, Малая кольцевая дорога, 21A; s.saidov.uz@ gmail.com)

\title{
ГОСУДАРСТВЕННАЯ МОЛОДЕЖНАЯ ПОЛИТИКА УЗБЕКИСТАНА
}

Аннотация. В статье автор анализирует государственную молодежную политику Узбекистана. В качестве неотъемлемой части молодежной политики он рассматривает национальную систему образования в стране. Автор анализирует результаты социологического опроса, проведенного в фокус-группах, на основании которого описывает виртуализацию социальных отношений среди молодежи.

Ключевые слова: молодежь, Узбекистан, система образования, виртуализация, социальные отношения

$\mathrm{C}$

егодня интеграцию социальных, политических, экономических и культур-

ных процессов во всем мире, быстрое распространение идей, инноваций и социальных изменений, возникших в одном уголке земного шара, на другие регионы мира можно рассматривать как феномен глобализации. Молодежь как движущая сила этих процессов играет здесь особую роль.

В Узбекистане молодежь занимает особое место в процессе формирования правового демократического государства и гражданского общества [Мирзиёев 2016]. Хорошо известно, что большинство населения узбекистанского общества - это молодые люди в возрасте до 30 лет. Признавая, что молодежь является решающей силой в модернизации общества, государство уделяет особое внимание воспитанию и поддержке молодого поколения. Это отражено в законе Республики Узбекистан «О государственной молодежной политике», принятом в новой редакции в сентябре 2016 г. ${ }^{1}$, и нескольких нормативно-правовых актах в стране.

\section{ВОЗРАСТНАЯ СТРУКТУРА НАСЕЛЕНИЯ РЕСПУБЛИКИ УЗБЕКИСТАН}

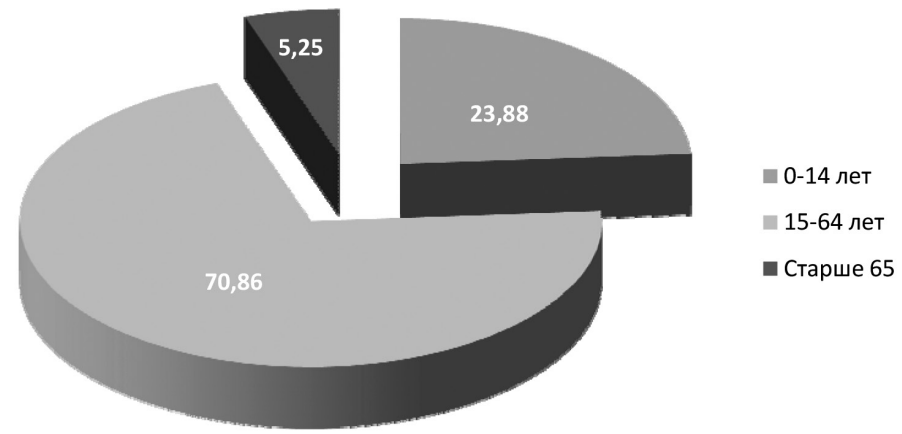

* По состоянию на 1 января 2018 г. численность населения Республики Узбекистан составила 32 653,9 тыс. чел.

Рисунок 1. Возрастная структура населения Республики Узбекистан

\footnotetext{
1 Закон Республики Узбекистан «О государственной молодежной политике». Доступ: https://nrm. uz/contentf?doc=474022_zakon_respubliki_uzbekistan_ot_14_09_2016_g_n_zru-406_o_gosudarstvennoy_ molodejnoy_politike_(prinyat_zakonodatelnoy_palatoy_12_08_2016_g_odobren_senatom_24_08_2016_g_)
} 


\begin{tabular}{|c|c|c|c|}
\hline Возраст & \multicolumn{2}{|c|}{ Наименование учебного заведения } & Уровень образования \\
\hline $29-31+$ & \multicolumn{2}{|c|}{ Докторантура (срок обучения не менее 3 лет) } & \multirow{2}{*}{$\begin{array}{l}\text { Послевузовское } \\
\text { образование }\end{array}$} \\
\hline $26-28$ & \multicolumn{2}{|c|}{ Базовая докторантура (срок обучения не менее 3 лет) } & \\
\hline \multirow[b]{2}{*}{$20-25$} & \multirow{2}{*}{$\begin{array}{l}\text { Профессиональные } \\
\text { программы высшего } \\
\text { образования } \\
\text { (медицина, срок обучения } \\
\text { не менее } 12 \text { лет) }\end{array}$} & $\begin{array}{l}\text { Магистратура } \\
\text { (не менее } 2 \text { лет) }\end{array}$ & \multirow[b]{2}{*}{$\begin{array}{l}\text { Высшее } \\
\text { образование }\end{array}$} \\
\hline & & $\begin{array}{l}\text { Программы общего } \\
\text { высшего образования } \\
\text { (бакалавриат, не менее } \\
4 \text { лет) }\end{array}$ & \\
\hline $17-19$ & $\begin{array}{l}\text { Академический лицей } \\
\text { (срок обучения } 3 \text { года) }\end{array}$ & $\begin{array}{l}\text { Профессиональный } \\
\text { колледж } \\
\text { (срок обучения } 3 \text { года) }\end{array}$ & $\begin{array}{l}\text { Среднее } \\
\text { специальное, } \\
\text { профессиональное } \\
\text { образование } \\
\end{array}$ \\
\hline $12-16$ & \multicolumn{2}{|c|}{ Общая средняя школа (срок обучения 5-7 лет) } & \multirow{2}{*}{$\begin{array}{l}\text { Общее среднее } \\
\text { образование }\end{array}$} \\
\hline $8-11$ & \multicolumn{2}{|c|}{ Начальная средняя школа (срок обучения 4 года) } & \\
\hline $4-7$ & \multicolumn{2}{|l|}{ II ступень } & Дошкольное \\
\hline $2-4$ & \multicolumn{2}{|l|}{ І ступень } & \\
\hline
\end{tabular}

Рисунок 2. Схема национальной системы образования в Узбекистане:

Каждый этап образования формируется и регулируется на основе закона «Об образовании», Национальной программы по подготовке кадров Республики Узбекистан и внутренних положений и уставов учреждений образования. Большинство молодежи заинтересовано в получении высшего образования. Еще с советских времен в узбекистанском обществе сложилось общее понимание особой роли диплома о высшем образовании в завоевании молодым человеком собственного места в обществе и в служебной карьере. Очень часто в реальной жизни ценится не интеллектуальный потенциал, а сертификат или диплом об образовании.

Сегодня действующие в стране более 9 тыс. общеобразовательных школ, 1500 академических лицеев, профессиональных колледжей и более 60 высших учебных заведений обеспечивают образование и воспитание молодежи. Сегодня, наряду с государственными органами, в сфере молодежной политики работают такие организации, как Союз молодежи Узбекистана, фонд «Истедод», благотворительный фонд «Махалла» и многие другие негосударственные общественные организации.

\section{Виртуализация социальных отношений молодежи}

В эпоху глобализации и информационно-коммуникационных технологий социально-политическое мировоззрение, социально-экономические проблемы молодежи меняются. Компьютеризация, развитие Интернета и социальных сетей создали по-настоящему виртуальную систему социальных отношений в среде молодежи. Признавая это как реальность, следует отметить, что данные процессы также создают негативные социальные факторы в молодежном социуме.

Число пользователей Интернета в Узбекистане превышает 14 млн чел., а число мобильных операторов превышает 22 млн $^{1}$, причем, как и во всем мире,

\footnotetext{
${ }^{1}$ Поданным Министерства по развитию информационных технологий и коммуникаций Республики Узбекистан. Доступ: http://mitc.uz/uz/
} 
основными пользователями Интернета и социальных интернет-сетей является, прежде всего, молодежь.

Естественно, возникают и определенные вопросы: какую роль сегодня играет Интернет в жизни молодежи? какое значение имеют виртуальные контакты для молодежи? чем занята сегодня молодежь в Интернете? По этим и аналогичным вопросам мы обратились к студентам Узбекского государственного университета мировых языков.

Большинство респондентов заявили, что Интернет имеет большое значение в их жизни, и отметили, что они используют сеть для общения и для ознакомления с новостями. На вопрос: «Можете ли вы представить свою жизнь без Интернета?» - почти 70\% респондентов ответили, что Интернет является частью их жизни, только $20 \%$ заявили, что Интернет не очень важен в их жизни, остальные затруднились с ответом.

Большинство молодых людей предпочитают виртуальное общение. Акцент делается на том, что в Интернете легко общаться, заключать дружеские отношения; в виртуальном общении можно более свободно выражать свои мысли, чем в реальной жизни. Некоторые респонденты считают, что диалог в социальных сетях хорош тогда, когда твои друзья находятся вдали от тебя, однако самое лучшее - это непосредственный контакт. Наиболее популярными социальными интернет-сетями среди узбекской молодежи являются Telegram, WhatsApp, Imo, Одноклассники, ВКонтакте и Facebook.

На вопрос: «Чем занята сегодня молодежь в Интернете?» - почти 85\% студентов, участвовавших в опросе, отвечали: «диалогом в социальных сетях». Далее следуют ответы: «отслеживанием местных и мировых новостей» $(7,1 \%)$ и «использованием Интернета в научных целях» (5\%). Некоторые студенты утверждают, что плата за Интернет является основной частью их ежедневных расходов.

Проведенное краткое исследование показывает важность использования Интернета и социальных сетей для молодежи. Современные информационнокоммуникационные технологии становятся неотъемлемой частью общественной жизни Узбекистана и превращают каждого человека в «абонента виртуального мира».

\section{Гражданская активность молодежи}

Политико-правовая культура и гражданская позиция населения, особенно молодежи, определяют уровень гражданской активности в стране. Сегодня молодежная активность проявляется во всех сферах жизни узбекского общества, в т.ч. в экономике и предпринимательстве [Каримов 2010]. По данным Торгово-промышленной палаты Республики Узбекистан, около $37 \%$ представителей бизнеса в стране - граждане до 35 лет.

В последние годы значительно возросла политическая активность молодежи. Участие молодых людей в политических партиях и общественных организациях растет (см. рис. 2).

Однако социально-политическую активность молодежи можно считать в некоторой степени односторонней. Сегодня их внимание в основном сосредоточено на поиске достойных рабочих мест и обеспечении своего экономического благополучия и благополучия своей семьи [Саидов, Тожихонов 2001]. Сложное социально-экономическое положение в стране, недостаточное внимание со стороны государства и общества и различные административные барьеры не позволяют молодежи занимать достойное место в обществе. Вот почему трудовая миграция, особенно среди молодого поколения, растет из года в год. 


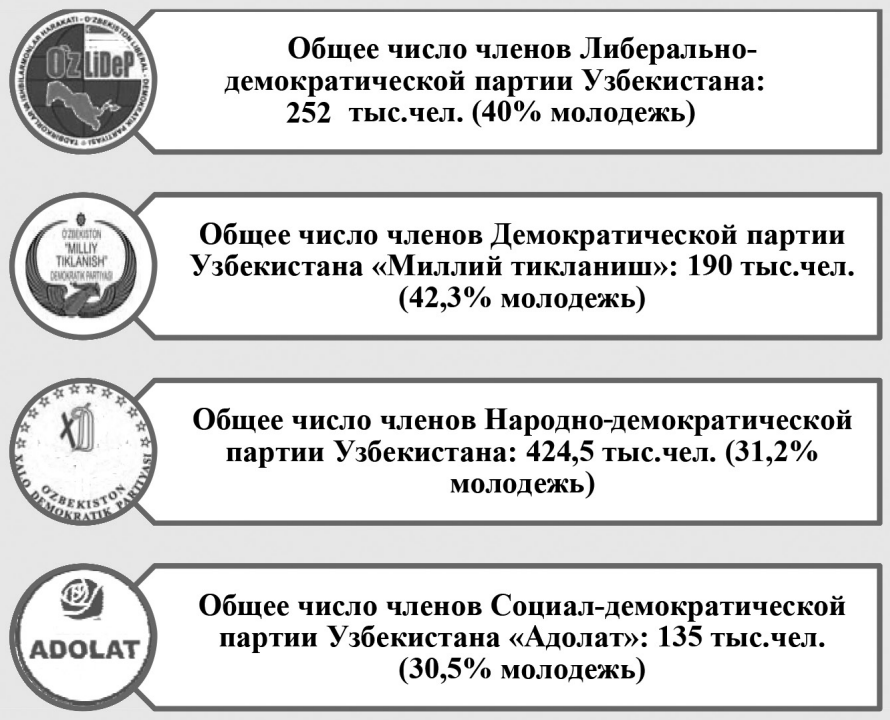

Рисунок 2. Участие граждан в деятельности политических партий

В результате данного анализа можно прийти к выводу, что государственная молодежная политика в настоящее время находится в кризисе и нуждается в реорганизации и пересмотре существующей поддержки со стороны государства и общества. Прежде всего, на наш взгляд, необходимо проявить волю для того, чтобы внедрить прозрачную и доступную для всех современную систему образования. Это отвечает и политическим, и экономическим интересам страны, т.к. только самодостаточные и образованные граждане способны обеспечить достойное будущее грядущему поколению.

\section{Список литературы}

Каримов И.А. 2010. По пути преодоления последствий мирового кризиса, модернизации страны и достижения уровня развитых государств. Ташкент, Узбекистан. T. $18.280 \mathrm{c.}$

Мирзиёев Ш.М. 2016. Мы все вместе построим свободное, демократическое и процветающее государство Узбекистан. Т.: Узбекистан. 53 с.

Саидов А., Тожихонов У. 2001. Давлат ва хукуқ назарияси. Т.: Узбекистан. 285 с.

SAYIDOV Sanzhar Shavkatovich, political scientist, Uzbek State University of Foreighn Languages (21A Small ring Road, Tashkent, Republic of Uzbekistan, Russia, 100138; s.saidov.uz@gmail.com)

\section{STATE YOUTH POLICY OF UZBEKISTAN}

Abstract. The article analyzes the state youth policy in Uzbekistan, emphasizes the national education system in the country as an integral part of youth policy and demonstrates the virtualization of social relations among young people, using the results of a sociological survey, conducted in focus groups. The author makes proposals aimed at further improving the system of support of young people by the state and society.

Keywords: youth, Uzbekistan, education system, virtualization, social relations 